DOROTA ŻOEĄDŹ-STRZELCZYK

Uniwersytet im. Adama Mickiewicza

w Poznaniu

\title{
„A CACEK TEŻ DUŻO BYŁO”. ZABAWKI DZIECIĘCE NA ZIEMIACH POLSKICH W ŚREDNIOWIECZU I EPOCE NOWOŻYTNEJ
}

Cytat zamieszczony w tytule pochodzi z pamiętnika Elżbiety z Rudominów Pakoszowej urodzonej w 1804 r., która poczyniła to spostrzeżenie, wspominając okres dzieciństwa ${ }^{1}$. Wbrew temu, co napisała pamiętnikarka i co zapewne oddawało ówczesną i wcześniejszą rzeczywistość, zachowane źródła różnego rodzaju niewiele mówią o dziecięcych zabawkach. Wspominając dzieciństwo, najczęściej z perspektywy przeżytych kilkudziesięciu lat, zapominano o dziecięcych zabawach i zabawkach, uznając je prawdopodobnie za nieważne. Chyba właśnie pamięcią, a raczej jej brakiem, należy tłumaczyć niewielką liczbę przekazów dotyczących dziecięcych zabawek. Brakiem pamięci, a nie brakiem zabawek, bo przecież dzieci na ziemiach polskich bawiły się zabawkami, podobnie jak te na innych terenach - to zauważyła wspomniana pamiętnikarka. Dzieci, niezależnie od pochodzenia, zamożności domu, płci, czasów, w których przyszło im się narodzić, zawsze się bawiły. Zabawa to przywilej dzieciństwa. Okres beztroskiego dzieciństwa bywał często krótki, ale zabawa i jej atrybuty - zabawki - nierozerwalnie związane są z początkowym okresem życia człowieka, chociaż i starsi z przyjemnością zabawom się oddawali.

Zabawki dziecięce najczęściej umykały uwadze zarówno piszących w przeszłości (niewiele odnajdujemy zapisów mówiących o nich w źródłach, szczególnie z czasów przedrozbiorowych) jak i historyków badających przeszłość ${ }^{2}$. Podobnie jak samo dzieciństwo, zabawki stały się przedmiotem

\footnotetext{
${ }^{1}$ E. z Rudominów Pakoszowa, Pamiętnik, ,Kronika Rodzinna” 1881, t. 9, nr 9, s. 276.

${ }^{2}$ W opracowaniu Historia kultury materialnej Polski w zarysie poświęcono zabawkom dziecięcym niewiele uwagi, por. chociażby t. 4, Od połowy XVII do końca XVIII wieku, red. Z. Kamieńska, B. Baranowski, Warszawa 1978, s. 373-374.
} 
naukowych analiz i studiów stosunkowo niedawno, a w polskiej historiografii prace im poświęcone są nieliczne i nie ukazują ich dziejów w sposób kompleksowy ${ }^{3}$, najczęściej wspomina się o nich na marginesie rozważań o dziecku. Inaczej sytuacja wygląda w przypadku historiografii zachodnioeuropejskiej, studia nad zabawkami mają w poszczególnych krajach dawną i bogatą tradycję i znaczny dorobek ${ }^{4}$. Najdawniejsze zabawki z ziem polskich znamy przede wszystkim dzięki odkryciom archeologów. W źródłach pisanych znajdujemy niewiele wzmianek na ten temat. To, co udało się odtworzyć na podstawie zarówno znalezisk archeologicznych, jak i informacji w źródłach pisanych pokazuje, że na naszych terenach występowały podobne zabawki jak na sąsiednich ziemiach. Stwierdzić można, że dzieci w różnych kulturach i czasach bawiły się zabawkami, różniącymi się niekiedy materiałem, z którego je wykonano czy jakością wykonania, ale kanon najstarszych zabawek zawiera podobne przedmioty służące dzieciom w zabawach. Są to grzechotki, bąki, zwierzęce figurki - bardzo często koni, elementy uzbrojenia - miniaturowe mieczyki, nożyki, groty strzał, lalki, miniaturowe przedmioty gospodarstwa domowego.

Odtworzony zbiór dawnych zabawek dziecięcych podzielić można na kilka grup ${ }^{5}$. Kryteria, jakie zastosowano przy ich wydzieleniu, to wiek dziecka, płeć, funkcja zabawki. Pierwsza grupa to zabawki związane z początkiem życia człowieka, z niemowlęctwem i wczesnym dzieciństwem. Do tej grupy należą grzechotki. Grzechotka była właściwie wyznacznikiem wczesnego dzieciństwa, co widać na ikonograficznych przedstawieniach dzieci, a także w źródłach pisanych. Kiedy dziecko trochę podrastało, bawiło się bąkami, wiatrakami. Przedstawiane na ilustracjach dzieci z takimi rekwizytami zabawy to przede wszystkim kilkuletni chłopcy, chociaż niekiedy są to dzieci nieco starsze. Tak więc w przypadku tych zabawek nie ma pewności, czy bawiły się nimi tylko małe dzieci i czy w związku z tym można je powiązać jednoznacznie z tym okresem w życiu człowieka.

${ }^{3}$ J. Bujak, Zabawki w Europie. Zarys dziejów - rozwój zainteresowań, Kraków 1988; T. Lewińska, Kolorowy świat zabawek. Zabawki ludowe w Polsce, Kielce 1995; D. Żołądź-Strzelczyk, Dziecko w dawnej Polsce, Poznań 2002 (fragm. „Zabawy i zabawki”, s. 169-189); M. Delimata, Dziecko w Polsce średniowiecznej, Poznań 2004 (fragm. „Zabawki i gry”, s. 95-101); K. Kabacińska, Zabawy i zabawki dziecięce w osiemnastowiecznej Polsce, Poznań 2007; Dawne i współczesne zabawki dziecięce, red. D. Żołądź-Strzelczyk, K. Kabacińska, Poznań 2010.

${ }^{4}$ Por. m.in. A. Fraser, Spielzeug. Die Geschichte des Spielzeugs in aller Welt, Oldenburg-Hamburg 1966; z nowszych prac: F. Meier, Von allerley Spil und Kurzweyl. Spiel und Spielzeug in der Geschichte, Ostfildern 2006; D. Jaffé, The history of toys. From spinning tops to robots, Phoenix Mill 2006. Ponadto wiele prac poświęconych dziejom konkretnych rodzajów zabawek, ewentualnie zbiorom poszczególnych muzeów.

${ }^{5}$ Typologie dawnych zabawek przeprowadzili m.in. N. Orme, Medieval children, London 2003, s. 167 n., ostatnio P. Blaževičius, Seniausieji Lietuvos žaislai, Vilnius 2011. 
Kolejny etap i kolejne rodzaje zabawek to już zróżnicowane pod względem płci, a więc przyszłych obowiązków, przedmioty zabawy. Dzieci ze względu na przynależność do określonej płci bawiły się odpowiednimi zabawkami, naśladując obserwowane zachowania i zajęcia dorosłych. Dziewczynki, ,wchodząc” w dorosłe kobiece role, odpowiednio bawiły się „,dziewczęcymi" zabawkami. Przygotowując się do roli matki - bawiły się lalkami, które pełniły w takich zabawach funkcję dzieci, a przygotowując się do zajmowania się domem - miniaturowymi naczyniami, mebelkami, domami dla lalek. Popularne w Europie Zachodniej, między innymi w Niemczech, domy dla lalek miały znaczącą funkcję dydaktyczną: pokazując idealny dom i jego wyposażenie, uczyły dziewczynki, jak powinien ich dom wyglądać ${ }^{6}$. Męskie zajęcia były liczniejsze i bardziej zróżnicowane, stąd różnorodność zabawek dla chłopców była większa. Wchodząc w męskie zajęcia, chłopcy mieli do dyspozycji miniaturowe narzędzia - przygotowujące do ról zawodowych, m.in. pracy w rzemiośle, środki transportu - łódki, wózki, wreszcie najbardziej popularne, związane z typowo wojskowymi zajęciami dorosłych mężczyzn zabawki militarne - elementy uzbrojenia, figurki żołnierzy, koniki. Do tej kategorii również zaliczyć można zabawki religijne, za pomocą których dzieci naśladowały zachowania księży w trakcie mszy, pogrzebu itp. Z biegiem czasu i w miarę rozwoju technologicznego, w toku przemian społecznych i cywilizacyjnych, wraz z powiększającą się specjalizacją zawodową, powstawaniem nowych zawodów itd. zasób zabawek w obrębie tej grupy powiększał się i różnicował.

I wreszcie przedmioty służące rozrywce - zabawki muzyczne (gwizdki, fujarki, piszczałki, bębenki), ruchowo-zręcznościowe (piłki, kręgle, kule, latawce, obręcze, szczudła). Trzeba zaznaczyć, że przedmioty znajdujące się w tej ostatniej grupie służyły nie tylko dzieciom, również dorośli wykorzystywali je, aby uprzyjemnić sobie czas. W niniejszym artykule przedstawione zostaną jedynie przedmioty służące dzieciom do zabawy, więc te, które zaliczyć można do ostatniej grupy, nie zostaną uwzględnione.

\section{Średniowiecze}

Jedną z najstarszych zabawek jest grzechotka, znana już w okresie prehistorycznym. Prawdopodobnie w najdawniejszych czasach jako grzechotki wykorzystywano wyschnięte części roślin, w których hałasowały suche pestki. Zabawka ta jest nie tylko jedną z najstarszych, ale też zwykle pierwszą - współcześnie jedną z pierwszych - zabawką dziecka.

\footnotetext{
${ }^{6}$ Por. H.A. Müller, Ein Idealhaushalt im Miniaturformat. Die Nürnberger Puppenhäuser des 17. Jahrhunderts, Nürnberg 2006.
} 
W przypadku tego przedmiotu nastąpiła prawdopodobnie swoista ewolucja od funkcji magicznej do ludycznej - w dwóch odmianach dziecięcej zabawki i instrumentu muzycznego. Grzechotka, wydając specyficzne dźwięki, bo przecież właśnie na tym polega jej zasadnicza funkcja, służyła z pewnością ochronie przed złymi mocami. Broniła dorosłych, a ponieważ dziecko jest istotą najbardziej narażoną na działanie rozmaitych mocy, służyła również ochronie dzieci. I właśnie te najmniejsze niemowlęta i małe dzieci - wyposażano w takie przedmioty lub, co bardziej prawdopodobne, biorąc pod uwagę ich ciężar (a najstarsze grzechotki wykonywano z gliny i wcale nie były takie lekkie), to dorośli potrząsali nimi, bawiąc lub chroniąc dziecko ${ }^{7}$. Grzechotka była także od dawna instrumentem muzycznym ${ }^{8}$. Najstarsze grzechotki miały kształt owalny lub zbliżony do takiego, ale mogły być zoomorficzne, niekiedy bywały w różny sposób zdobione. Wraz z postępem technologicznym zmieniały się kształty, zdobienia, kolorystyka. Takie przedmioty znajdowali archeolodzy w Gdańsku ${ }^{9}$, Bytomiu Odrzańskim ${ }^{10}$, Kołobrzegu ${ }^{11}$ i wielu innych miejscach. W Poznaniu na przykład podczas badań na Ostrowie Tumskim znaleziono gliniane grzechotki - jedna z nich ma kształt jajka i też podobne do niego rozmiary, jest zielonego koloru, zdobiona brunatnymi „łuczkami", druga natomiast ma kształt kuli o średnicy $3,5 \mathrm{~cm}$ z niesymetrycznie rozmieszczonymi guzkami. W obydwu są otworki, przez które prawdopodobnie wkładano do środka kamyki, w pierwszej otwór ten jest zalepiony masą szklanąa ${ }^{12}$. Średniowieczne grzechotki miały rozmaite kształty, najczęściej pisanki różnorodnie zdobionej lub kuli z guzkami.

Wzmianki o grzechotce znajdujemy w Kronice Mistrza Wincentego, który pisał o przepowiadaniu Siemowitowi wysokich godności „od czasów jego dziecięcych grzechotek"13. Jednoznacznie wiązał grzechotkę z dzie-

${ }^{7}$ A. Tamboer, Dźwięki z przeszłości. Archeologiczne instrumenty muzyczne na przestrzeni wieków. Wystawa prezentowana w Muzeum Instrumentów Muzycznych, maj-wrzesień 2000, Poznań 2000, s. 46.

${ }^{8}$ W. Hensel, Polska starożytna, Wrocław 1973, s. 237.

${ }^{9}$ Ł. Kunicka-Okulicz, Wczesnośredniowieczne zabawki i gry z Gdańska, w: Gdańsk wczesnośredniowieczny, t. 1, red. J. Kamińska, Gdańsk 1959, s. 130.

${ }^{10}$ T. Borkowski, Gry i zabawy w średniowiecznym mieście na Ślasku. Ślady materialne, w: Kultura średniowiecznego Śląska i Czech. Miasto, red. K. Wachowski, Wrocław 1995, s. 104.

${ }^{11}$ Kołobrzeg. Wczesne miasto nad Bałtykiem, red. L. Leciejewicz, M. Rębkowski, Warszawa 2007, s. 80.

${ }^{12}$ O. Antowska-Gorączniak, O rozrywkach poznaniaków wieków średnich. Zabawki i przedmioty do gier z Ostrowa Tumskiego, „Kronika Miasta Poznania” 2003, 1: W kregu katedry, s. 76-77.

${ }^{13}$ Mistrza Wincentego Kronika Polska, tł. K. Abgarowicz, B. Kürbis, oprac. B. Kürbis, Warszawa 1974, s. 98. 
ciństwem, i to z pewnością wczesnym dzieciństwem. Zabawka ta towarzyszyła dzieciom przez wiele stuleci i do dzisiaj obecna jest w dziecięcych pokojach i łóżeczkach, chociaż przebyła długą drogę od swoich początków do czasów współczesnych.

Podobnie częstymi znaleziskami w różnych miejscach i warstwach osadniczych są bąki (Gdańsk, Szczecin, Kołobrzeg). Wykonywano je przede wszystkim z drewna, znane są egzemplarze wystrugane, ale i toczone, niektóre mniej lub bardziej zdobione. Podstawową funkcją bąków było wirowanie; niekiedy dodatkowo wydawały dźwięki. Wyróżnić można kilka rodzajów bąków w zależności od sposobu wprawiania ich w ruch - te najprostsze i często najmniejsze poruszano palcami, inne przy użyciu nawijanego sznurka, który rozwijano, rzucając bąkiem, jeszcze inne za pomocą biczyka, którym podcinano bąki, wreszcie za pomocą patyka wtykanego w specjalny otwór w górnej części zabawki. Znane są one również z wielu średniowiecznych przedstawień ikonograficznych, niestety nie z naszych terenów. Można powiedzieć, że bąki należały do atrybutów dzieciństwa i bawili się nimi, sądząc z ikonografii, głównie chłopcy.

Nie posiadamy pochodzących z ziem polskich wczesnych przedstawień tego rodzaju przedmiotów zabawy, rekompensują to w pewnym stopniu znaleziska archeologiczne. W Gdańsku znaleziono drewniane bąki we wszystkich poziomach osadniczych, ale najwięcej było ich w tych datowanych na wiek XII. Z Pomorza Zachodniego pochodzi wiele egzemplarzy odkopanych w różnych miejscowościach i różnych warstwach w Szczecinie, Wolinie, Kołobrzegu. Te z terenów Szczecina są stożkowate, dochodzą do $8 \mathrm{~cm}$ wysokości, jeden ma w górnej części poziome żeberka - być może przeznaczone do nawijania sznurka. Większość została wystrugana nożem, jeden nosi ślady toczenia ${ }^{14}$. Znalezione w Poznaniu egzemplarze datowane są na okres od początku XI do połowy XIII w. Mają od 3,5 do $6 \mathrm{~cm}$ wysokości, na jednym z nich widać dookolne rowki, służące do nawijania sznurka ${ }^{15}$. Znaleziska elbląskie wskazują, że największa popularność tego typu zabawek przypadła na wieki XIV i XV, chociaż znaleziono także egzemplarze z XIII w. i późniejsze, które datować można na XVII i XVIII stulecie ${ }^{16}$.

Wśród zabawek charakterystycznych dla tego okresu wymienić można m.in. łódki z kory wystrugane na wzór łodzi używanych przez dorosłych.

${ }^{14}$ A. B. Kowalska, Życie codzienne mieszkańców wczesnośredniowiecznego Szczecina w świetle źródeł archeologicznych, w: A. B. Kowalska, M. Dworaczyk, Szczecin wczesnośredniowieczny. Nadodrzańskie centrum, Warszawa 2011, s. 339.

${ }^{15}$ O. Antowska-Gorączniak, op. cit., s. 78.

${ }^{16}$ M. Marcinkowski, Zabawki dzieci elblaskich. Prezentacja zbioru z badań wykopaliskowych, w: Dawne i wspótczesne zabawki dziecięce, s. 57. 
Sposób wykonania niektórych egzemplarzy wskazuje, że mogły być one samodzielnie zrobione przez dzieci. Takie łódki znaleziono w Gdańsku, Szczecinie i w innych miejscowościach leżących blisko akwenów. W Szczecinie znalezione egzemplarze datowane są na XI-XIII w., mają kształt owalny ze spiczastymi zakończeniami lub elipsoidalny, zostały wystrugane $\mathrm{z}$ drewna lub kory, niekiedy zrobiono je z uszkodzonych pływaków. Niektóre egzemplarze mają niewielkie otwory, być może były w nich umocowane małe maszty. Ich wielkość jest różna, największe mają do $20 \mathrm{~cm}^{17}$. W Szczecinie znaleziono również miniaturowe wiosło ${ }^{18}$.

Chłopcy zawsze chętnie bawili się zabawkami militarnymi. Były to różnego rodzaju drewniane mieczyki, nożyki, groty strzał, miniaturowe kusze. Części tych ostatnich - drewniane łoża kusz - znaleziono podczas wykopalisk w Elblągu. Datuje się je na przełom XV i XVI w. Wykonane z jednego fragmentu drewna, mają doskonale zachowane poszczególne części - wyraźnie widać miejsce przeznaczone do osadzenia bełtu, zachowane są urządzenia spustowe służące zwalnianiu cięciwy ${ }^{19}$. Chłopcy bawili się także miniaturowymi mieczami. Sporządzone z drewna, mają różne rozmiary - być może powiązane $\mathrm{z}$ wiekiem dziecka, dla którego były przeznaczone. Znalezione w Szczecinie egzemplarze datowane na wieki od X do XIII osiągają długość do $34 \mathrm{~cm}$. Mają dwusieczne ostrza, a rękojeść jednego z nich zakończoną jest owalną głowicą ${ }^{20}$. Mieczyki z XI i XII w. odkopano również w Wolinie $^{21}$.W Elblągu znaleziono między innymi mieczyk długości aż $84 \mathrm{~cm}$ pochodzący z XIV lub XV w. ${ }^{22}$

Ulubioną zabawką dawnych chłopców były koniki, te najstarsze to rozmaite figurki koni, ewentualnie konia z jeźdźcem, wreszcie, jak wnosić można z ikonografii, chłopcy „,jeździli” na patykach zastępujących konie. Wzmiankę o takiej zabawce spotykamy w Kronice Kadłubka, według którego „dzieci [- - ] zwyczajem jest [- - ] na długiej trzcinie harcować" ${ }^{23}$. Ta długa trzcina czy patyk zastępowały konia. Widzimy tę zabawkę także w źródłach ikonograficznych, m.in. na bordiurze w Graduale Jana Olbrachta z 1501 r. przedstawiono chłopca „dosiadającego" takiego drewnianego konia. Jest to kij zakończony wyrzeźbioną dosyć realistycz-

${ }^{17}$ A.B. Kowalska, op. cit., s. 338-339, il. 213, 4-8.

${ }^{18}$ Ibidem, s. 339, il. 213, 13.

${ }^{19}$ M. Marcinkowski, op. cit., s. 61.

${ }^{20}$ A.B. Kowalska, op. cit., s. 339-340.

${ }^{21}$ M. Rulewicz, Wczesnośredniowieczne zabawki i przedmioty do gier z Pomorza Zachodniego (z badań prowadzonych w latach 1947-1959), „Materiały Zachodniopomorskie” 4, 1958, s. 321-322.

${ }^{22}$ M. Marcinkowski, op. cit., s. 61.

${ }^{23}$ Mistrza Wincentego Kronika Polska, s. 218. 
nie głową zwierzęcia. „Jeździec” pogania wierzchowca bacikiem trzymanym w ręce, w drugiej zaś ma cugle ${ }^{24}$.

Figurki koników wykonywane były głównie z gliny, biorąc pod uwagę technologie wykonania, najprawdopodobniej w tych samych warsztatach ceramicznych co naczynia, zarówno te miniaturowe, jak normalne, duże. Część wytworzono w warsztatach miejscowych, część zaś przywieziono z innych terenów, głównie z ziem niemieckich. Gliniane figurki koników znaleziono na terenie Wrocławia, część z nich jest osiodłana, niektóre mają jeźdźców na grzbiecie ${ }^{25}$. Niekiedy koniki wykonane zostały z drewna, a ślady na części z nich wskazują, że mogły mieć doczepiane grzywy i ogony, ze sznurka lub włosia. Figurkami takimi bawili się chłopcy przez wiele stuleci $^{26}$.

Dziewczynki natomiast chętnie bawiły się lalkami. Z czasów średniowiecza niewiele ich pozostało na naszych ziemiach, prawdopodobnie dlatego, że były robione głównie $\mathrm{z}$ drewna ${ }^{27}$, być może samodzielnie przez dziewczynki z patyków, niekiedy owiniętych gałgankami. Najstarsze znaleziska tego typu to między innymi, datowana na IX-XII w., pochodząca z Wolina wystrugana z patyka postać ludzka ze schematycznie zaznaczonymi nosem, oczami i ustami. Z X w. natomiast pochodzi antropomorficzny przedmiot odkryty w Kołobrzegu ${ }^{28}$, a z XIII i XIV w. drewniane figurki z Elbląga. Te ostatnie są już nader realistyczne, bardziej przypominają postać ludzką, widać więcej istotnych elementów. Obok drewnianych występowały w okresie średniowiecza również gliniane lalki, o takich wspomniał w swojej kronice Kadłubek ${ }^{29}$.

Prawdopodobnie zabawkami dziewczynek były również rozmaite naczynia miniaturowe, znajdowane w różnych warstwach osadniczych, chociaż mogły one pełnić również inne funkcje. Między innymi w Szczecinie w warstwie datowanej na X-XIII w. znaleziono kilka naczyń glinianych będących zapewne zabawkami dziecięcymi. Są to miseczki o wysokościach ok. $3 \mathrm{~cm}$ i średnicach wylewów od 4,8 do $6,1 \mathrm{~cm}$. Wykonano je ręcznie i wysuszono na powietrzu. Jedno naczynie staranniej wykonane $\mathrm{z}$ warstwy datowanej na XII w. zostało zrobione prawdopodobnie w pracowni

${ }^{24}$ Malarstwo gotyckie $w$ Polsce. Album ilustracji, red. A. Labuda, K. Secomska, Warszawa 2004, il. 1069.

${ }^{25} \mathrm{~T}$. Borkowski, Rozrywka - zabawki i drobna plastyka figuralna, w: Ze studiów nad życiem codziennym w średniowiecznym mieście. Parcele przy ul. Więziennej 10-11 we Wrocławiu, red. C. Buśko, J. Piekalski, Wrocław 1999, Wratislavia Antiqua, t. 1, s. 190 n.

${ }^{26}$ M. Marcinkowski, op. cit., s. 59-60.

${ }^{27}$ I. Gomułka, Drewniane średniowieczne lalki z badań archeologicznych, w: Dawne i współczesne zabawki dziecięce, s. $23 \mathrm{n}$.

${ }^{28}$ Kołobrzeg. Wczesne miasto nad Bałtykiem, s. 57, il. 58, 15.

${ }^{29}$ Mistrza Wincentego Kronika Polska, s. 73. 
garncarskiej ${ }^{30}$. Podobne miniatury naczyń znane są również z Gdańska ${ }^{31}$. Znalezione w Poznaniu małe naczynia mają „ślady dziecięcych palców"32, co świadczy o tym, że dzieci nie tylko bawiły się takimi przedmiotami, ale niekiedy same je wykonywały.

Najstarsze pochodzące z Elbląga naczynia datowane są na XIV i XV w. Znaleziono ich stosunkowo dużo i wyraźnie nawiązują one, zarówno pod względem technicznym, technologicznym, jak i stylistycznym, do tych wykorzystywanych przez dorosłych. Były one z pewnością wykonywane przez tych samych garncarzy. Znaczna część przywieziona została, podobnie jak normalne naczynia, przez kupców, głównie niemieckich. Pozostałe wykonali miejscowi garncarze - m.in. wypalane na kolor siwy miniaturowe egzemplarze ${ }^{33}$.

Dzieci bawiły się jeszcze innymi przedmiotami, znajdowanymi podczas wykopalisk - wykorzystywały do zabaw przedmioty ze swego otoczenia - patyki, kamyki, kości zwierząt. Do gier i zabaw używano różnego rozmiaru kul wykonanych z drewna, kamienia, gliny lub szkła. Z pewnością niekiedy do zabawy dzieciom służyły także różnego rodzaju instrumenty muzyczne ${ }^{34}-$ dzwonki, piszczałki, gwizdki, flety, bębenki.

\section{Czasy nowożytne XVI-XVIII w.}

W okresie nowożytnym podstawowy asortyment zabawek właściwie niewiele się zmienił. Zmieniły się natomiast technologie ich wytwarzania i zdobienia. Wraz z rozwojem technologii zabawki stawały się większe, ładniejsze i trwalsze. Pojawiły się w Europie ośrodki produkcyjne specjalizujące się w ich wytwarzaniu i kupcy rozwożący je po całym prawie kontynencie. Przybywali oni również na ziemie polskie, podobnie polscy kupcy wśród wielu różnych towarów przywozili zabawki dla dzie$\mathrm{ci}^{35}$, ponadto istnieją źródła potwierdzające fakt produkowania zabawek

${ }^{30}$ A. B. Kowalska, Życie codzienne mieszkańców, s. 339; eadem, M. Dworaczyk, op. cit., „Aneks 4”, ryc. 213, 11-12.

${ }^{31}$ M. Rulewicz, op. cit., s. 320.

32 O. Antowska-Gorączniak, op. cit., s. 78.

${ }^{33}$ M. Marcinkowski, op. cit., s. 63.

${ }^{34}$ A. Tamboer, op. cit., s. 42-52.

${ }^{35} \mathrm{~W}$ zbiorze zachowanych poznańskich inwentarzy mamy m.in. spis ruchomości zrobiony po śmierci kupca norymberskiego Andrzeja Pegniczera. Wśród jego rzeczy wymienione również zostały zabawki dziecięce, co świadczy o tym, że kupcy niemieccy je przywozili, por. Inwentarze mieszczańskie z lat 1528-1635 z ksiag miejskich Poznania, oprac. S. Nawrocki, J. Wiesiołowski, Poznań 1961, s. 102-104; podobnie w inwentarzu ruchomości należących do kupca świdnickiego Kaspra Helwika widzimy sporo różnych zabawek, por. M. Gutkowska-Rychlewska, Zabawki dziecinne w I poł. XVII w., ,,Polska Sztuka Ludowa"10, 1956, 3, s. 196. 
w Gdańsku ${ }^{36}$. Niestety stosunkowo niewiele można powiedzieć o zabawkach, którymi bawiły się dzieci żyjące w czasach nowożytnych na terenach Rzeczypospolitej. Informacje w tym zakresie są bardzo skąpe. Nawet po zestawieniu tych przekazanych przez źródła pisane z przekazami ikonograficznymi i zachowanymi w zbiorach muzealnych egzemplarzami zabawek i tak pozostaje wrażenie ubóstwa informacji na ten temat. Konieczne staje się więc skrupulatne przeanalizowanie tego, czym dysponujemy, i korzystanie z możliwości porównywania z zasobami z innych terenów.

Przegląd nowożytnych zabawek dziecięcych na ziemiach polskich rozpoczniemy, podobnie jak w przypadku średniowiecznych, od grzechotek, zabawek najmłodszych - niemowląt i małych dzieci. Grzechotki w XVI w. i w następnych stuleciach były inne od tych znanych ze średniowiecznych wykopalisk. Bardziej skomplikowane zarówno pod względem kształtu i konstrukcji, jak i materiału, z którego je wykonano. Te nowożytne grzechotki, znane z ikonografii, były metalowe srebrne, nawet złote, niekiedy zdobione kamieniami, oprócz wartości ludycznej, a z pewnością emocjonalnej, miały także, z racji materiału, z którego zostały wykonane, wartość materialną. Były z pewnością drogie i świadczyły o pozycji i majątku rodziców ${ }^{37}$. Widzimy je na obrazach malarzy zachodnioeuropejskich, począwszy od wieku XVI. Co ciekawe, wiele takich grzechotek z dzwoneczkami zachowało się do dnia dzisiejszego i znajduje się w muzeach lub prywatnych kolekcjach w Europie i Ameryce ${ }^{38}$.

Specyficzny kształt tych grzechotek nasuwa przypuszczenie, że miały one także funkcje dzisiejszych gryzaków i gwizdków. Niekiedy w literaturze określa się je jako flety-smoczki - i opisywane są w następujący sposób: „to w zasadzie rodzaj grzechotki - jedna końcówka przeznaczona była do ssania lub gryzienia, po przeciwnej stronie znajdował się flet, a w środku cztery dzwoneczki"39. Składały się z kilku części - kawałka korala lub innego kamienia, niekiedy kryształu górskiego, ewentualnie kła wilka, i z zasadniczej części z umocowanymi dzwoneczkami, na drugim końcu bywał umieszczony otwór, który stanowił część gwizdka lub piszczałki ${ }^{40}$.

${ }^{36}$ Zachowany inwentarz po tokarzu gdańskim Jacobie Steffenie zawiera m.in. drewniane zabawki, por. A. Klonder, Wszystka spuścizna w Bogu spoczywajacego. Majątek ruchomy zwykłych mieszkańców Elblaga i Gdańska w XVII wieku, Warszawa 2000, s. 85.

${ }^{37}$ Pride and joy. Children's portraits in the Netherlands 1500-1700, red. J. B. Bedaus, R. Ekkart, Amsterdam 2001, s. 298.

${ }^{38}$ I. Schäfer, Klingendes Spielzeug. Kinderrasseln aus aller Welt, Duisburg 1991.

${ }^{39}$ A. Tamboer, op. cit., s. 14.

${ }^{40}$ G.S. Sturtz, Early American Baby Rattles, „Clinical Pediatrics” 11,1972, 2, s. 103. 
Niekiedy uważane są za piszczałki, fujarki - tak zinterpretowano przedmiot trzymany przez małego Krasińskiego sportretowanego w wieku pięciu miesięcy ${ }^{41}$. Być może niektóre były bardzo uproszczone, może była to piszczałka z dzwoneczkami, w którą przekształcić się mogły wcześniejsze bardziej skomplikowane i urozmaicone zabawki. Na zachowanych do dnia dzisiejszego egzemplarzach podobno nadal można gwizdać. Umieszczany w nich kieł wilka miał chronić dziecko przez urokami i dodawać sił. Podobnie wierzono, że koral chroni od złego, a ponadto, że pokazuje stan zdrowia dziecka - kiedy było ono zdrowe, koral miał ciemno czerwoną barwę, a kiedy chorowało, bladł ${ }^{42}$.Zabawka taka miała więc potrójną funkcję: była grzechotką - wydawała dźwięki, była gwizdkiem lub piszczałką - na jednym końcu miała specjalny otwór, w który można było dmuchać, by zagwizdać, wreszcie była gryzakiem, przynoszącym ulgę podczas ząbkowania. Zachowane egzemplarze mają niekiedy ślady żucia czy gryzienia odciśnięte na wmontowanych kamieniach lub wilczych kłach ${ }^{43}$.

$\mathrm{W}$ dawnym malarstwie $\mathrm{w}$ polskich zbiorach nie mamy niestety zbyt wielu przedstawień dzieci trzymających grzechotki. Jest ich zaledwie kilka: m.in. w zbiorach Muzeum Narodowego we Wrocławiu znajduje się portret dziewczynki z różańcem namalowany w 1651 r., przechowywany wcześniej w zbiorach Maltzanów w Miliczu ${ }^{44}$, oraz portret dziecka z niezapominajką z drugiej połowy XVIII w. pochodzący ze zbiorów rodziny Schaffgotschów z Cieplic ${ }^{45}$. W Muzeum Warmii i Mazur w Olsztynie znajdują się dwa portrety małych dzieci trzymających tego typu zabawkę - portret dziewczynki z rodziny Dohnów z około 1770 r. ${ }^{46}$ oraz portret Konstancji Treusch von Buttlar trzymającej w rączce grzechotkę ${ }^{47}$. Dziewczynka z rodziny Dohnów trzyma przedmiot, w którym wyraźnie zauważyć można trzy wyróżnione wcześniej części - końcówkę do gryzienia, korpus z kuleczkami (dzwoneczkami?) i końcówkę do gwizdania ze specjalnym otworem, takim, jaki mają współczesne gwizdki. Natomiast w Muzeum Narodowym w Krakowie przechowywany jest siedemnastowieczny portret nieznanej rodziny mieszczańskiej

${ }^{41}$ Pastelowe portrety osobistości polskich końca XVII-XIX wieku, oprac. J. Waniewska, Warszawa 1993, nr 36, s. 59.

${ }^{42}$ G.S. Sturtz, op. cit., s. 105.

${ }^{43}$ Pride and joy, s. 64-65.

${ }^{44}$ Malarstwo śląskie 1520-1800. Katalog zbiorów, red. E. Houszka, Wrocław 2009, s. 209, nr 151, nr inw. VIII-2394.

${ }^{45}$ Ibidem, s. 387, nr 416, nr inw. VIII-1688.

${ }^{46}$ Muzeum Warmii i Mazur w Olsztynie, nr inw. MNO 400 OMO. Obraz został opublikowany w albumie Dziecko w malarstwie od XVI do końca XVIII wieku ze zbiorów polskich, red. E. Micke-Broniarek, M. Ochnio, E. Zdonkiewicz, Warszawa 2004, nr 146, s. 380-381.

${ }^{47}$ Muzeum Warmii i Mazur w Olsztynie, nr inw. MNO 329 OMO. 
u stóp Chrystusa ${ }^{48}$. Dwoje najmłodszych dzieci, prawdopodobnie chłopiec i dziewczynka - dzieci ubrane są w identyczne sukienki z fartuszkami, czepki na głowach, ale jedno przedstawione zostało po „męskiej”, drugie po „kobiecej” stronie obrazu, stąd wnosić można o ich płci trzymają w rączkach grzechotki umocowane na sznurkach i zawieszone na szyjach. Ponadto w zbiorach Muzeum Narodowego w Warszawie mamy portret Józefa Wawrzyńca Krasińskiego z 1783 r. pochodzący z Muzeum Ordynacji Krasińskich ${ }^{49}$, a w Muzeum w Koszalinie portret Wilhelma Ludwika Adolfa von der Goltz z 1798 r. namalowany przez Teodora Friedricha Tietza ${ }^{50}$. Obydwaj chłopcy trzymają zabawki tego właśnie rodzaju. W zbiorach fundacji Yannick y Ben Jakober na Majorce, gromadzącej m.in. dziecięce portrety z dawnych wieków, znajdują się dwa obrazy przedstawiające małego chłopca. Są to według katalogu wystawy z 2004 r., na której prezentowano część zbiorów fundacji, portrety Stanisława Leszczyńskiego. Na jednym z nich chłopiec trzyma złotą grzechotkę wysadzaną perłami - byłoby to kolejne przedstawienie tej zabawki związane z polskimi realiami ${ }^{51}$.

Grzechotka towarzysząca portretowanemu dziecku służyła podkreśleniu jego wieku, przedstawiano z nią chłopców lub dziewczynki w początkowym okresie życia. Często nie można określić płci portretowanego dziecka, jeżeli nie wiemy, kogo konkretnie przedstawia obraz. Ustalenie, czy to dziewczynka, czy chłopiec, może okazać się niemożliwe dlatego, że małe dzieci ubierane były bardzo podobnie - w stroje, które dzisiaj określilibyśmy jako dziewczęce (proste, przewiewne i wygodne koszulki lub sukienki, niekiedy z fartuszkami, i czepki na główkach). Na portretach rodzinnych wśród wielu dzieci najmłodsze trzymają w rękach grzechotki, tak jak to widzimy na obrazie z Krakowa. Wspomniane portrety pochodzące z polskich muzeów przedstawiają właśnie takie najmłodsze dzieci - J.W. Krasiński został sportretowany w wieku pięciu miesięcy, von der Goltz - niecałych dwóch lat (urodził się w marcu 1796 r., został namalowany w styczniu 1798 r., jak zapisano na odwrocie obrazu). Dzieci przedstawione na portretach z Muzeum Warmii i Mazur też pewno nie są starsze - jedno z nich ubrane w białą luźną koszulkę siedzi - jak często

${ }^{48}$ Muzeum Narodowe w Krakowie, nr inw. I-707, por. D. Żołądź-Strzelczyk, K. Kabacińska-Łuczak, Codzienność dziecięca opisana słowem i obrazem. Życie dziecka na ziemiach polskich od XVI do XVIII wieku, Warszawa 2012, il.141.

${ }^{49}$ Muzeum Narodowe w Warszawie, $\mathrm{nr}$ inw. 183680. Por. Pastelowe portrety osobistości polskich, s.59, także D. Żołądź-Strzelczyk, K. Kabacińska-Łuczak, op. cit., il. 50.

${ }^{50}$ Por. D. Żołądź-Strzelczyk, K. Kabacińska-Łuczak, op. cit., il. 49.

${ }^{51}$ Kleine Prinzen. Kinderbildnisse vom 16. bis 19. Jahrhundert aus der Fundación Yannick y Ben Jakober, Bonn 2004, s. 56-57. 
portretowano dzieci w tym wieku - na poduszce. Obok nieco starszej dziewczynki na stoliku odłożono noszone ówcześnie przez uczące się chodzić dzieci specjalne ochronne nakrycie głowy, co świadczyć może o wieku dziecka.

Ślady takich przedmiotów znajdujemy w spisach ruchomości, w których określano je mianem ząbków dziecinnych, między innymi w inwentarzu pośmiertnym małżonków Sobiechowiczów, piwowarów poznańskich, widzimy: „ząbek dziecinny w srebro oprawny 1, dzwonyszków od tegoż ząbka 2, trzonek srebrny od ząbka 1 "52, w innym podobnie znajdujemy „ząbek dziecinny z 2 dzwonyszkami” oraz „ząbek dziecinny w kryształ, [- - ] dzwonyszek od ząbka"53. Inwentarz pośmiertny Anny Brunclowej z 1767 r. przynosi nam więcej szczegółów: „ząbek staroświecki, srebrny, z 3 gruchawkami, przy którym jest malutki, koralowy ząbek i 2 kamyszki oprawne, jeden biały, drugi szary waży ze wszystkim łutów 3 "54. Jeden raz wspomniano "gruchał dziecinne" ${ }^{55}$. Podobnie w inwentarzach z innych terenów - „paćka dziecinne to jest ząbków dwa” zanotowano w spisie z Jarosławia ${ }^{56}$.

Do zabawek przeznaczonych dla małych dzieci zaliczyć możemy również przedmiot pokazany na dziecięcym portrecie Władysława IV. Ten zaczynający swoistą galerię dziecięcych portretów króla obraz namalowany został przez Marcina Kobera i przedstawia królewicza w wieku około ro$\mathrm{ku}^{57}$. Dziecko trzyma w ręce drewnianego misia grającego na dudach, podobnego do tych zabawek, które jeszcze dzisiaj kupić można w sklepach czy na straganach z drewnianymi wyrobami ${ }^{58}$. Władysław miał również inne zabawki dostosowane do wieku, w 1598 r., jak czytamy w jednym z listów słanych z polskiego dworu do teściowej Zygmunta III arcyksiężnej Marii Bawarskiej, bawił się lalkami ${ }^{59}$. Być może były to lalki wyobrażające męskie postacie.

${ }^{52}$ Inwentarze mieszczańskie z wieku XVIII z ksiag miejskich Poznania, t. 1: 1700-1758, oprac. J. Burszta, C. Łuczak, Poznań 1962, s. 32.

${ }^{53}$ Ibidem, s. 45-46.

${ }^{54}$ Inwentarze mieszczańskie z wieku XVIII z ksiag miejskich Poznania, t. 2: 1759-1793, oprac. iidem, Poznań 1965, s. 45.

${ }^{55}$ Inwentarze mieszczańskie z wieku XVIII, t. 1, s. 108.

${ }^{56}$ K. Kieferling, Jarosław w czasach Anny Ostrogskiej. Szkice do portretu miasta i jego właścicielki (1594-1635), Przemyśl 2008, s. 201.

${ }^{57}$ J. Petrus, Portrety dziecięce Władysława IV i Anny Marii Wazówny w zbiorach hiszpańskich (ze studiów nad malarstwem dworskim epoki Wazów), „Folia Historiae Artium” 11, 1975, s. 110; por. także D. Żołądź-Strzelczyk, K. Kabacińska-Łuczak, op. cit., il. 105.

${ }^{58}$ B.Fabiani, Życie codzienne na zamku królewskim w epoce Wazów, Warszawa 1996, s. 64.

${ }^{59}$ W. Leitsch, Das Leben am Hof König Sigismunds III. von Polen, Wien 2009, s. 1618. 
Kolejna zabawka to znany nam już bąk, chętnie uwieczniany na rozmaitych przedstawieniach ikonograficznych, zwany cygą albo frygą. Szczególnie często widzimy dzieci bawiące się bąkami w ikonografii niderlandzkiej, i to zarówno na obrazach, jak i na przedstawieniach innego typu - drzeworytach czy też na kafelkach, na których umieszczano w czasach nowożytnych sceny różnych zabaw dziecięcych, między innymi właśnie chłopców $\mathrm{z}$ bąkami ${ }^{60}$. Polska ikonografia jest pod tym względem niezwykle uboga, mamy właściwie jedno przedstawienie dziecka z taką zabawką na wizerunku Wielkiej Rodziny z kościoła św. Rocha ze Stobiecka z 1519 r. Chłopców bawiących się frygami widzimy ponadto na jednym z rysunków z cyklu przedstawiającego zabawy dziecięce Daniela Chodowieckiego.

Równie skromne są opisy tej zabawki w źródłach pisanych. Zabawę cygą wymienia wśród ,igrzysk i zabaw dziecinnych przystojnych" Sebastian Petrycy z Pilzna ${ }^{61}$. Wspomniał o niej między innymi Andrzej Kochanowski, opisując zabawę cygą w następujący sposób:

Jaką po długich salach grą się bawią dzieci,

W długiem kole patrzając,

Ta biczmi pędzona, krzywem kołem polata ${ }^{62}$.

Widzimy w tych słowach istotę zabawy tą zabawką - dzieci stawały w kole i puszczały bąka podtrzymując jego ruch poprzez podcinanie go biczykiem, a zabawka krążyła, zataczając coraz to inne koła.

Nawiązywanie do zabawy bąkiem służyło podkreślaniu szybkiego ruchu, kręcenia się i ten motyw pojawia się w staropolskiej poezji. Wykorzystali go między innymi Łazarz Baranowicz czy Franciszek Gościecki. U pierwszego czytamy:

Serce jako cyga, gdy ją zacinają

Obrot ustalon z cygi z zajęciem miewają.

Serce jak cyga nasze obrot stroi,

Pańskiego bicia jak cyga się boi ${ }^{63}$.

Gościecki zaś pisał:

póki szybko, jak cyga kręcąc między niemi ${ }^{64}$.

${ }^{60}$ J. Pluis, Kinderspelen op tegels, Assen 1979.

${ }^{61}$ S. Petrycy z Pilzna, Przydatki do Polityki Arystotelesowej, w: idem, Pisma wybrane, t. 2, oprac. W. Wąsik, Warszawa 1956, s. 467.

${ }^{62}$ Cyt. za Z.Gloger, Encyklopedia staropolska ilustrowana, t. 1, Warszawa 1989, s. 254.

${ }^{63}$ Ibidem, s. 254.

${ }^{64}$ Cyt. za M. Prejs, Egotyzm w literaturze staropolskiej. Wybrane problemy, Warszawa 1999, s. 157. 
W tych fragmentach podobnie widzimy, na czym polegała zabawa zabawka „zacinana” kręci się i „boi się” bicia, czyli użycia bacika do podtrzymania jej ruchu.

O popularności zabawy bąkiem świadczy do dzisiaj używane powiedzenie „bąki zbijać”, czy mniej znane obecnie, ale kiedyś popularne „bąki strzelać”, „za bąkami chodzić”, co oznaczało tracić czas na dziecinną zabawę z bąkiem ${ }^{65}$. Wśród zabaw opisanych przez Łukasza Gołębiowskiego na początku XIX w. znajdujemy opis tej zabawki i sposoby bawienia się za jej pomocą: „cyga, kręglica, bąk, fryga, wartołka, warchołka, wydrążona to kula na pręciku u spodu przymocowana, w około którego sznurek okręcony; gdy się ta cyga albo bąk w otwór udzielnej na to rączki wsadzi, a rzemień lub sznurek odciągnie, raptem wyskakuje i z nadaną sobie mocą po podłodze się kręci z hukiem stopniowo gasnącym. Niekiedy cygę biczem ocucają, żeby nie ustawała. Od wieków cyga u nas znana"66.

Analizując zarówno przedstawienia ikonograficzne, jak i zachowane opisy oraz sięgając do bogatych zasobów źródłowych z terenów Europy Zachodniej, wyróżnić można kilka rodzajów bąków ${ }^{67}$. Niektóre z nich odnaleźć można w polskich źródłach. Zabawki te wykonywane były z drewna, początkowo - jak już wspomniano - mogły być strugane, z czasem toczone. Pierwszy, najprostszy rodzaj to mały bączek wprawiany w ruch palcami. Może on mieć kształt kulisty z umocowanym w górnej części patyczkiem albo na patyczku umocowany jest lekko spłaszczony korpus bączka. Drugi rodzaj to zabawka o kształcie najczęściej stożkowatym z rowkami w szerszej części służącymi do łatwiejszego umocowania sznurka. Zawinięty wokół bąka sznurek w momencie rzutu zabawką zostawał w ręce, a rzucony bąk dzięki temu wprawiano w ruch wirowy na płaskiej powierzchni podłogi czy podwórka. Kolejny rodzaj to zabawka poruszana za pomocą biczyka. Bywały jeszcze takie, w które wtykano kijek i nim wprawiano cygę w ruch obrotowy. Tych kilka wymienionych rodzajów bąka odnaleźć można również w polskich realiach - na rysunkach lub w źródłach pisanych. Na przedstawieniu ze Stobiecka widzimy pierwszy albo ostatni z opisanych rodzajów. Na rysunku Chodowieckiego przedstawieni zostali chłopcy podcinający bąki biczykami. Wśród nowożytnych bąków znalezionych przez archeologów w Elblągu mamy przykłady takich właśnie zabawek, przy których wykorzystywano zawijany na nich sznurek. Za pomocą specjalnego

${ }^{65}$ Z. Gloger, op.cit., t. 1, s. 137.

${ }^{66}$ Ł. Gołębiowski, Gry i zabawy różnych stanów w kraju całym lub w niektórych tylko prowincjach, Warszawa 1831, s. 12-13.

${ }^{67}$ R. Holler, Kreisel, München 1989; L. Bas, A. Verdoorn, The Lost Art of Spinning Tops, Erm 2011. 
urządzenia i sznurka wprawił w ruch swego bąka jeden z chłopców narysowanych przez Chodowieckiego.

Na zachowanych przedstawieniach widzimy chłopców bawiących się bąkami, pozostańmy więc w kręgu zabaw chłopięcych. Podobnie jak w okresie średniowiecza chłopcy chętnie ,jeździli” na koniach. Najczęściej były to głowy końskie osadzone na patyku, te wytwarzane również i dzisiaj „koniki na patyku”. Koniki takie znane były na różnych terenach, w różnych okresach historycznych. Ich wygląd, stopień podobieństwa do prawdziwych koni, wyposażenie w elementy uzdy uwarunkowane były środowiskowo i przez możliwości finansowe rodzin. Najbiedniejsi „dosiadali” zwykłego kija. W późniejszych polskich źródłach znajdujemy również opisy takich „koników”. U Dymitra Michała Krajewskiego, autora Gry nauk dla dzieci, czytamy, że „jeżdżenie na koniu drewnianym lub tego nie mając, na kiju jeżdżenie podoba się dziecięciu" ${ }^{68}$. W pochodzących z początku XIX w. Ł. Gołębiowskiego Grach i zabawach również czytamy o takiej zabawce: „chłopczyk i sam jeden, byle miał bicz i lada kijek, przeistacza się w jeźdźca; już mu ów konik bryka, wierzga i niespokojnym się stawi, zacina go i powolnym być sobie zmusza"69. Wspomina taką zabawę w swoim pamiętniku Józef Rulikowski urodzony w 1731 r.: „,raz harcowałem na kijach zastępujących konie z mojemi rówieśnikami"70. Koniki wymieniają spisy ruchomości, szczególnie te pozostałe po kupcach czy rzemieślnikach. W pochodzącym z 1569 r. spisie pośmiertnym kupca norymberskiego zmarłego w Poznaniu Andrzeja Pegniczera wśród zachowanych po nim przedmiotów znajdujemy między innymi „36 koników dziecińskich"71, być może były to właśnie takie koniki na patyku.

Niestety w polskich zbiorach niewiele mamy przedstawień dzieci z taką zabawką, a te, które posiadamy, pochodzą głównie z wieku XVIII, chociaż w malarstwie europejskim ten motyw pojawia się znacznie wcześniej. Występuje on na najbardziej chyba znanym obrazie przedstawiającym bawiące się dzieci, namalowanym przez Pietera Bruegela Starszego, zatytułowanym Zabawy dziecięce. Widzimy na nim chłopczyka jadącego na takim właśnie kiju z końską głową. Podobnie na innych ilustracjach ukazujących dziecięce zabawy dostrzec można chłopca na

${ }^{68}$ D. M. Krajewski, Gry nauk dla dzieci. Służace do ułatwienia i edukacyi. Przez które łatwo nauczyć się moga: poznawania liter, syllabizowania, czytania w polskim i francuskim ięzyku. Formowania charakteru, pisania, języków ze zwyczaiu, historyi, geografii i początków arytmetyki, Kraków 1777, s. 51.

${ }^{69}$ Ł. Gołębiowski, op. cit., s. 12.

${ }^{70}$ Urywek wspomnień Józefa Rulikowskiego wydany z obszerniejszego rękopisu (173192 r.), Warszawa 1862, s. 102.

${ }^{71}$ Inwentarze mieszczańskie z lat 1528-1635, s. 102-103. 
drewnianym koniku - m.in. u Maertena van Cleve (1570), Jacoba von der Heyden (1632) czy Adriaena van der Venne i Jacoba Catsa. Motyw dziecka trzymającego konika występuje w malarstwie hiszpańskim (Alonzo Sánchez Coello), niderlandzkim (Jan van Ravesteyn ${ }^{72}$ czy Johanna Vergouwen ${ }^{73}$ ).

W zbiorach polskich muzeów znajduje się zaledwie kilka podobnych motywów. Najstarsze przedstawienie to obraz z 1586 r. znanego malarza Antona Möllera przedstawiający syna burmistrza gdańskiego Bartłomieja Schachmanna znajdujący się w Dziale Sztuki i Rzemiosła Artystycznego Muzeum w Gliwicach. Chłopiec w prawej ręce trzyma konika, a w lewej szczygła. Konik nie ma nóg, jest to „popiersie” konia, ale jest on bogato przybrany, wyposażony w uzdę, wyróżnić można jej elementy - wodze, nagłówek, nachrapnik. W nagłówku umieszczono białe pióra ${ }^{74}$.

W Muzeum Okręgowym w Pile znajdziemy portret brata znanego nam już Wilhelma Goltza - Karola Jerzego, portret powstały podobnie jak poprzedni w 1789 r., namalowany również przez T. Tietza. Ukazany na nim chłopiec ma cztery lata,jest więc starszy od brata i trzyma nie jak on grzechotkę, ale drewnianego konika. W tym przypadku konik to właściwie sama głowa osadzona na kiju, chłopiec trzyma go nie za wodze, ale za przewiązaną dookoła szyi rumaka tasiemkę ${ }^{75}$. Kolejny przykład to portret nieznanego chłopca, być może z rodziny Potockich, jak zapisano na odwrocie obrazu, przechowywany w Muzeum Miejskim w Zabrzu. Obraz datowany jest na koniec XVIII w. Chłopczyk ma drewnianego konika, którego trzyma za wodze lewą ręką, a prawą podnosi do góry bacik. Wyrzeźbiony z drewna konik cechuje się pewną , kanciastością”, ma uprząż, ale wygląda ona jak namalowana, a wodze są doczepione $e^{76}$.

Chłopców dosiadających koniki dostrzec można także na innego rodzaju przedstawieniach, m.in. w scenie Pozwólcie dziatkom przyjść do mnie ze Staniątek, z pierwszej połowy XVII w. Widzimy na niej dwóch małych chłopców jeżdżących na patykach. Z kościoła Świętej Trójcy w Tarłowie z XVII w. pochodzi kolejne wyobrażenie dzieci wyposażonych w takie zabawki. Jest to przedstawienie z cyklu taniec śmierci i obejmuje kilka elementów. Na jednym z nich widać kilkoro dzieci oraz wyobrażenie śmierci. Dzieci mają w ręku zabawki - jedno z nich właśnie takiego konika na patyku, dwoje innych wiatraki osadzone na długich kijkach. Takie wiatracz-

\footnotetext{
72 Por. Pride and joy, s. 147-148.

${ }^{73}$ Ibidem, s. 269-270.

${ }^{74}$ Aurea Porta Rzeczypospolitej. Sztuka Gdańska od połowy XV do końca XVIII wieku, [t. 1:] Katalog, red. T. Grzybkowska, J. Talbierska, Gdańsk 1997, s. 221.

${ }^{75}$ D. Żołądź-Strzelczyk, K. Kabacińska-Łuczak, op. cit., il. 146.

${ }^{76}$ Ibidem, il. 147.
} 
ki bardzo często trzymały dzieci jeżdżące na koniach na patyku wyobrażane w sztuce zachodnioeuropejskiej ${ }^{77}$.

W zbiorach Muzeum Archeologiczno-Historycznego w Elblągu znajduje się datowana na wiek XVIII część takiego właśnie konia na patyku. Wykonana z drewna, wycięta z jednej szerokiej deski o grubości 1-2 cm. Zachowana część ma długość $21 \mathrm{~cm}$, nie zachował się kijek, którego „dosiadano". Prawdopodobnie fakt, iż się ułamał, spowodował, że zabawka stała się nieprzydatna, została wrzucona do latryny, gdzie ją po wiekach znaleziono. Konik ma nawet otwór, przez który można przewlec sznurek służący jako wodze. Jest to w polskich warunkach znalezisko wyjątkowe ${ }^{78}$.

Obok koników na patyku dzieci bawiły się również innymi zabawkami wyobrażającymi konie i możemy je odnaleźć na osiemnastowiecznych obrazach. W polskich zbiorach mamy jedno przedstawienie konia na biegunach. Na znajdującym się w Muzeum Narodowym w Warszawie obrazie widzimy ,jadącego" na takim koniu Stanisława Septyma Potockiego, syna Stanisława Szczęsnego i jego pierwszej żony Józefy Amalii z Mniszchów. Chłopiec w chwili malowania obrazu miał 5, może nawet 6 lat. Płótno namalowane zostało w 1788 r., a Stanisław Septym urodził się w 1782 r., chociaż malarz, a był to niejaki Lépine, przedstawił go młodszego ${ }^{79}$. Ubrany w strój polski, namalowany został w pozie nawiązującej do tradycyjnych portretów konnych. Zabawka nie została prawdopodobnie wyprodukowana w Polsce, zapewne kupił ją podczas jednego ze swoich zagranicznych pobytów ojciec chłopca. Konia odtworzono bardzo realistycznie, jest osiodłany z bogato zdobioną uprzężą. Tak zamontowano go na biegunach, że wygląda, jakby rwał się do skoku. Koń na biegunach to bardzo popularna od dawien dawna zabawka dziecięca, do dzisiaj lubiana przez najmłodszych. Najstarszy zachowany do naszych czasów egzemplarz pochodzi z początku wieku XVII i był własnością króla Karola I Stuarta, kiedy był chłopcem ${ }^{80}$.

Koniki różnego rodzaju i jazdę na nich widzimy na ilustracjach D. Chodowieckiego i Michała Stachowicza ${ }^{81}$. Pierwszy w swoim cyklu rysunków „Zabawy dziecięce” sportretował dwóch chłopców bawiących się takimi zabawkami. Jeden z nich „dosiada” konika na kijku. Koń ma realistycznie odtworzoną głowę, a chłopiec pogania go batem trzymanym

${ }^{77}$ Ibidem, il. 138 oraz 145.

${ }^{78}$ M. Marcinkowski, op. cit., s. 62.

${ }^{79}$ Dziecko w malarstwie, s. 372-372.

${ }^{80}$ P. Mullins, The Rocking Horse. A history of moving toy horses, London 1992, s. 25-32.

${ }^{81} \mathrm{~K}$. Kabacińska, Dziecko na wybranych przedstawieniach ikonograficznych Michała Stachowicza (1768-1825), „Studia Edukacyjne” 2010, 12, s. 181-200. 
w prawej ręce, w lewej natomiast trzyma wodze ${ }^{82}$. Drugi z jeźdźców ma konia na biegunach, odtworzonego także ze szczegółami, podobnie jak jego towarzysz zabaw w jednej ręce ściska wodze, w drugiej trzyma bat do poganiania rumaka ${ }^{83}$. Na kartach ze sztambucha M. Stachowicza widzimy trzech małych jeźdźców ${ }^{84}$. Dwóch na koniach na patyku, jeden na koniu na biegunach. Wszyscy trzymają baciki. Koń na biegunach wymieniony został $\mathrm{w}$ inwentarzu pośmiertnym spisanym po poznańskim kotlarzu Salomonie Tybermanie zmarłym w 1792 r.: „1 koń drewniany do huśtania dzieci"\$5. Dzieci bawiły się konikami jeszcze innego rodzaju, mianowicie małymi konikami na kółkach, które można było ciągnąć na sznurku. Taką zabawkę widzimy na portrecie Szczęsnego Potockiego $\mathrm{z}$ rodziną, jeden z młodszych chłopców, Jarosław lub Włodzimierz, ciągnie na sznurku konika na kółkach, drugi trzyma biczyk ${ }^{86}$.

Mali mężczyźni bawili się, podobnie jak wcześniej, zabawkami militarnymi. Były to kusze, miecze czy szabelki, karabiny mniej lub bardziej realistycznie odtworzone ${ }^{87}$. Niekiedy wykorzystywano do zabawy zwyczajny kij, któremu wyobraźnia dziecka nadawała kształty i funkcje.Chłopca strzelającego z patyka i leżącą kuszę widzimy na ilustracji z dzieła Jana Amosa Komeńskiego Świat zmysłowy w obrazach ${ }^{88}$. Podobnie na rycinie D. Chodowieckiego przedstawieni zostali maszerujący chłopcy ubrani w mundury, „uzbrojeni” w karabiny, szable albo strzelający z kuszy. W zbiorach Muzeum Pałacu w Wilanowie znajdują się elementy uzbrojenia ochronnego przeznaczonego dla chłopca: pochodzące z wieku XVII zbroja kolczo-płytowa - tzw.juszman, nakrycie głowy - misiurka, pancerz oraz osiemnastowieczna tarcza ${ }^{89}$. Niestety nie posiadamy źródeł świadczących o tym, że również u nas chłopcy przed końcem XVIII w. bawili się tak popularnymi w całej Europie figurkami żołnierzyków, wytwarzanych głównie z cyny. Ślady zabaw cynowymi figurkami mamy dopiero z wieku XIX ${ }^{90}$.

${ }^{82}$ Eadem, Zabawy i zabawki dziecięce, il. 58.

${ }^{83}$ Ibidem, il. 60.

${ }^{84}$ Por. eadem, Dziecko na wybranych przedstawieniach, s. 194-195, il. 3 i 4.

${ }^{85}$ Inwentarze mieszczańskie z wieku XVIII, t. 2, s. 290.

${ }^{86}$ Portret Szczęsnego Potockiego z rodziną, Muzeum-Zamek w Łańcucie, nr inw. 7779Mt.

${ }^{87} \mathrm{~J}$. Ryś, Zabawki militarne w okresie staropolskim, w: Dawne i współczesne zabawki dziecięce, s. 142.

${ }^{88}$ Por. Dawne zabawy dziecięce, red. D. Żołądź-Strzelczyk, K. Kabacińska, KielceWarszawa 2008, s. 30.

${ }^{89}$ Tron pamiątek ku czci „Najjaśniejszego, Niezwyciężonego Jana III Sobieskiego Króla Polskiego" w trzechsetlecie śmierci 1696-1996, (katalog wystawy), red. J. Meleszko, Warszawa 1996, s. 137-138, zdjęcie 58.

${ }^{90}$ A. Winiarz, Świat zabawek i zabaw dzieci polskich $w$ dobie niewoli narodowej (17951918), w: Dawne i współczesne zabawki dziecięce, s. 104. 
I wreszcie zabawki dziewczynek - lalki, naczynia dla lalek, mebelki i domki. Zabawy i zabawki od zawsze miały funkcję socjalizacyjną, czyli przygotowywały do odgrywania ról w społeczeństwie. Dlatego też część zabaw była i nadal jest przynależna płci, chociaż czasami bawią się w takie zabawy zarówno dziewczynki, jak i chłopcy. Odmienność zabaw dziewczęcych dostrzegał Ł. Gołębiowski, pisząc: „płeć ta od lat najmłodszych ma w zabawach swoich różniące ją od chłopców łatwo dostrzegane cechy. Gry dziewczątek mniej szumne, nie tyle za sobą pociągające hałasu, więcej w nich spokojności, dziewiczego wdzięku, lubej układności i chęci podo-

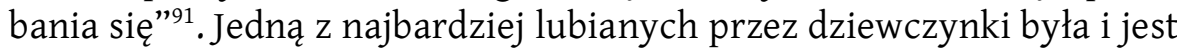
zabawa lalką. Lalka jako przedmiot ma nie tylko funkcję ludyczną, ale także magiczną, obrzędową. Lalka to nie tyko znana nam, przypominająca człowieka w różnych fazach życia figurka, ale może to być, jak bywało dawniej często i jak bywa niekiedy dzisiaj - kijek owinięty gałgankami. Wyobraźnia dziecka nadaje mu kształty i przypisuje czynności. Zabawy z lalką są różnorodne, zmieniały się i nadal zmieniają w zależności od okoliczności - wraz z wiekiem dziecka, zainteresowaniami i pragnieniami dzieci, ich możliwościami itp.

W XVI-XVII w. w literaturze pięknej pojawiają się wzmianki o zabawach „łątkami”, co rozszyfrowuje się jako zabawy lalkami zrobionymi ze szmatek lub z kijka, ewentualnie łyka lipowego. Wspominał o takiej zabawie łątkami Jan Brożek: „Pamiętam u przyjaciela mego jednego dwoje dziewczątek małych, we czterech lat jedno, drugie w piąci, które za piecem ubierały łątki, a zwały je dzieciami; gdy je już w szmaty uwinęły i sznurami uwiązały, sprzeczały się: moje piękniejsze; drugie zaś: nie twoje, moje; oto oczki u niego piękniejsze, gębusia mała. Usłyszawszy, przystąpię do tak sławnej kontrowersyjej, obaczę, rozwinę, aliści szczapy smolne; roześmiałem się i odszedłem rzekłszy: «Ubierajcież, miłe dziatki»"92. Motyw łątki pojawia się w poezji staropolskiej, m.in. u Wacława Potockiego czytamy o „łątce z wosku" ${ }^{93}$. Wiemy, że lalki zbierała od dzieciństwa pierwsza żona Zygmunta III Wazy Anna. Jako dorosła osoba nie porzuciła zainteresowań lalkami, o czym dowiedzieć się można z jej korespondencji z matką Marią Bawarską. Królowa zamawiała nagie lalki w Augsburgu i szyła dla nich ubrania, w powiększaniu zbioru pomagała jej matka, która tradycje „zabawkowe" wyniosła z rodzinnego domu i jako dorosła kobieta, matka kilkanaściorga dzieci, przywiązywała dużą wagę do zabawek, obdarowując

${ }^{91}$ Ł. Gołębiowski, op. cit., s. 26.

92 J. Brożek, Gratis, w: idem, Wybór pism, t. 1, oprac. H. Barycz, Warszawa 1956, s. 348.

${ }_{93}$ W. Potocki, Disce domi, qualis debeas esse foris, w: Wacława Potockiego Moralia (1688), wyd. T. Grabowski, J. Łoś, t. 1, Kraków 1915, s. 479. 
nimi swe dzieci, w tym Annę. Niestety nie wiadomo, co się stało ze zbiorem lalek Anny po jej śmierci ${ }^{94}$.

O zabawie lalkami pisał także w początkach XIX w. wspomniany Gołębiowski: „pierwszą zabawą chłopców konik i biczyk, pierwszą dziewcząt lalka, jak gdyby przeznaczenie swe zgadywała, z lalką się pieści, kołysze ją, przyśpiewuje jej, usypia, to ją hojda, to do łona swego przytula, daje piersi, w sukienkę ubiera i rozbiera, strofuje, czasem dawane sobie przestrogi do niej zwracając, ją ucząc, jak ma być dobrą, żeby ją mama kochała i tatko" 95 .

W nowożytnym malarstwie zachodnim, na obrazach niderlandzkich, angielskich, francuskich pojawia się motyw dziewczynki z lalką ${ }^{96}$. W sztuce staropolskiej jest on właściwie nieobecny. Spośród portretów znajdujących się w naszych muzeach lalkę widzimy jedynie na znajdującym się w Muzeum Śląska Cieszyńskiego portrecie trzech córek aptekarza z Cieszyna Eliasza Hausera. Obraz przedstawia Franciszkę Romanę, Barbarę Józefę Teresę i Beatę Otylię Jadwigę ${ }^{97}$. W roku powstania obrazu - $1790-$ były one w wieku kolejno 10, 8 i 3 lat. Najmłodsza siedzi w wysokim dziecięcym krzesełku, po bokach stoją starsze siostry, jedna z nich trzyma ptaszka, po którego rączką sięga także najmłodsza dziewczynka. Stojąca $z$ drugiej strony krzesełka średnia Barbara Józefa Teresa w rączce opartej o krzesełko najmłodszej trzyma niewielką laleczkę. Zabawka ubrana jest w różową sukienkę i w zawinięty na ramionach biały szal. Można tutaj wymienić także namalowany przez Gustawa Fryderyka Tauberta po 1787 r. portret dziecka z pajacykiem znajdujący się w Muzeum w Nieborowie i Arkadii $^{98}$.

Nieco bogatsze pod tym względem są innego rodzaju przedstawienia ikonograficzne; na rysunkach wspomnianych twórców - D. Chodowieckiego i M. Stachowicza widzimy dziewczynki bawiące się lalkami. Pierwszy na jednej z tablic przedstawiających zabawy dziecięce ukazał zabawy dziewczynek. Młodsze bawią się właśnie lalkami, które ubrane są w stroje dorosłych kobiet, chociaż jedna z nich leży w kołysce, a więc pełni funkcję niemowlęcia, drugą trzyma na rękach bawiąca się nią dziewczynka, wreszcie trzecia lalka siedzi na krześle, a „mama” poprawia jej

${ }^{94}$ W. Leitsch, op. cit., s. 1292-1293.

${ }^{95}$ Ł. Gołębiowski, op. cit., s. 26.

${ }^{96}$ D. Żołądź-Strzelczyk, Dawne zabawki dziecięce - opisane słowem i obrazem, w: Dawne i współczesne zabawki dziecięce, s. $100 \mathrm{n}$.

${ }^{97}$ I. Adamczyk, Sztuka baroku. Katalog zbiorów Muzeum Śląska Cieszyńskiego. Malarstwo. Rzeźba, Cieszyn 2005, s. 40; por. także D. Żołądź-Strzelczyk, K. Kabacińska-Łuczak, op. cit., il. 125.

${ }^{98}$ Por. D. Żołądź-Strzelczyk, K. Kabacińska-Łuczak, op. cit., il.144. 
sukienkę. Obok inne dziewczynki przygotowują dla lalek przyjęcie. Za stół służy „dorosły” taboret, ale krzesełka mają już wielkość dopasowaną do wzrostu dziewczynek ${ }^{99}$. Na rysunku przedstawiającym rodzinę artysty widzimy lalkę leżącą na środku stołu, przy którym siedzą dzieci ${ }^{100}$. Lalki znajdują się również na straganie z zabawkami na innymi rysunku Chodowieckiego ${ }^{101}$. Podobnie na jednym ze szkiców ze sztambucha Stachowicza widzimy dziewczynki bawiące się lalką, a na innym obok kolejnej panienki zajętej robótkami, na niskim stoliku leży odłożona kolejna taka zabawka ${ }^{102}$.

Polskie, znajdujące się obecnie w polskich muzeach, wreszcie nawiązujące do polskich realiów przedstawienia są nieliczne i informacje o tej zabawce są niestety bardzo skąpe. Nie możemy na ich podstawie właściwie nic powiedzieć o materiałach, z których lalki robiono, jak je robiono. Nie było na naszych ziemiach wielu producentów lalek, dziewczynki jeżeli miały lalki, to były to głównie zabawki sprowadzane. Wyjątkową wartość ma więc pochodzący z Gdańska datowany na 1696 r. inwentarz ruchomości po zmarłym tokarzu Jacobie Steffenie ${ }^{103}$, w którym wśród spisanych przedmiotów wymienione są lalki -30 gotowych i 28 niewykończonych. Niestety jedyne, co możemy powiedzieć o tych zabawkach, to to, że wykonano je z drewna. I jest to jedyny ślad po produkcji lalek i innych zabawek w tym czasie na naszych ziemiach, przy czym - niestety - podkreślić należy fakt określonej przynależności kulturowej miasta, z którego pochodzi wspomniany inwentarz. W innym gdańskim spisie ruchomości po kupcu Johannie Remmersonie figuruje wózek z lalką ${ }^{104}$.

Więcej powiedzieć możemy o lalkach, którymi bawiły się małe mieszkanki Elbląga. Znalezione fragmenty tych zabawek świadczyć mogą o tym, że były one zrobione $\mathrm{z}$ drewna, a z czasem produkowano ich główki i kończyny z porcelany lub fajansu, pozostałe zaś części z surowców nietrwałych, m.in. z materiału ${ }^{105}$. Nowożytne lalki zachowały się w większości we fragmentach, przetrwały te części, które wykonane były z trwalszych materiałów - fajansowe główki z odpowiednio uformowanymi fryzurami, rączki, nóźki niekiedy w butach czy całe torsy lalek. Niestety zdecydowana większość zachowanych elementów tego rodzaju

\footnotetext{
${ }_{99}$ Por. K. Kabacińska, Zabawy i zabawki dziecięce, il. 22.

${ }^{100}$ Ibidem, il. 19 oraz 52.

101 Ibidem, il. 54.

102 Por. eadem, Dziecko na wybranych przedstawieniach, s. 192-193, il. 1 i 2.

103 Por. A. Klonder, op. cit., s. 85; AP Gdańsk, 300,5/821, s. 33-36.

${ }^{104}$ Ibidem, s. 87.

${ }^{105}$ M. Marcinkowski, op. cit., s. 59.
} 
zabawek znalezionych w Elblągu pochodzi z późniejszego okresu ${ }^{106}$. Zasoby polskich muzeów są ubogie w lalki datowane na interesujące nas czasy, wśród nielicznych zabytków tego rodzaju wspomnieć można niemiecką lalkę woskową z XVIII w. znajdującą się w Muzeum Zabawek i Zabawy $\mathrm{w}$ Kielcach ${ }^{107}$ oraz dekoracyjne woskowe lalki przechowywane w zbiorach Muzeum Warmii i Mazur w Olsztynie, również z XVIII stulecia ${ }^{108}$.

Dziewczynki na naszych ziemiach bawiły się zapewne lalkami w dom i miały wśród swoich zabawek także małe mebelki i naczynia do tych lalczynych domów. Takie miniaturowe naczynia z czasów nowożytnych znaleziono podczas wykopalisk na terenie Gdańska i Elbląga. Naczynia z Elbląga, których asortyment w czasach nowożytnych, podobnie jak ich „normalnych” pierwowzorów, uległ znacznemu wzbogaceniu, są wykonane z gliny. Należą one do najczęściej znajdowanych podczas wykopalisk przedmiotów związanych z zabawami dziecięcymi wymienić tu należy: garnki, kubki, grapeny, patelnie, dwojaki, talerze czy późniejsze dzbanuszki i filiżanki ${ }^{109}$. W Gdańsku natomiast znaleziono miniaturowe naczynia cynowe również zróżnicowane pod względem kształtu i przeznaczenia ${ }^{110}$. Są to rozmaite talerzyki, miseczki, dzbanuszki, koszyczki; ich niewielkie rozmiary pozwalają uznać je za dziecięce zabawki.

$\mathrm{Z}$ okresu staropolskiego nie mamy właściwie śladów istnienia odrębnych izb czy komnat dziecięcych. Jeżeli takowe były, to znajdowały się tylko w najzamożniejszych domach czy pałacach i prawdopodobnie dopiero w wieku XVIII. Dzieci zagospodarowywały do zabaw przestrzeń dorosłych, tak jak to opisuje w swoim pamiętniku urodzona w $1766 \mathrm{r}$. w Gdańsku Joanna Schopenhauer, która razem z młodszą siostrą, Lottą, chodziła bawić się „między okno a szafę, do przydzielonego [- - do

${ }^{106}$ A. Drążkowska, Nowożytne lalki w zbiorach Muzeum Archeologiczno-Historycznego w Elblagu, w: Dawne i wspótczesne zabawki dziecięce, s. 69-77.

${ }^{107}$ A. Myśliwiec, Zabawki w zbiorach polskich muzeów, w: Dawne i współczesne zabawki dziecięce, s. 335 (w artykule zaprezentowane zostały wyniki przeprowadzonej głównie na podstawie katalogów ogólnej kwerendy w zbiorach polskich muzeów, które wskazują, że zasoby te zawierają zabawki w większości dziewiętnasto- i dwudziestowieczne).

${ }^{108}$ K. Jackowska, Zabawki oraz motywy ludyczne w zbiorach ikonograficznych Muzeum Warmii i Mazur w Olsztynie, w: Dawne i współczesne zabawki dziecięce, s. 353.

${ }^{109}$ M. Marcinkowski, op. cit., s. 63-65.

110 Gdańskie znaleziska w większości czekają na opracowanie. Zabytki pochodzące ze zbiorów Muzeum Archeologicznego w Gdańsku zobaczyć można na wystawie w Spichlerzu „Błękitny Baranek”, zbiór kilkunastu cynowych zabawek znaleziony został ostatnio podczas badań archeologicznych w Gdańsku prowadzonych przez Roberta Krzywdzińskiego (m.in. miniaturowe naczynia - talerzyki, dzbanki, kufle, łyżeczki, kółka, grzechotki). 
zabawy narożnika, który pięknie urządziłam jako pokój mojej lalki"111. Takie kąciki zajęte przez małe dziewczynki widzimy także na rycinach D. Chodowieckiego z cyklu „Zabawy dziecięce”. Wśród mebli przeznaczonych dla dorosłych - krzeseł, obok łoża dziewczynki porozstawiały swoje meble - mniejsze krzesła, taborety, ławeczkę i zabawki - kołyskę, lalki, naczynia stołowe. Ich zabawy, zróżnicowane w zależności od wieku, doskonale wpisują się w świat dorosłych i go naśladują. Młodsze dziewczynki bawią się w dom - opiekują się lalkami-dziećmi, a starsze, wystrojone jak dorosłe kobiety, bawią się w przyjęcie. Na kolejnej rycinie z tego cyklu widzimy nieco starszą dziewczynkę wożącą w wózku młodsze dziecko, które nosi specjalne nakrycie głowy chroniące w razie upadku. Wózek jest wiklinowy, ma cztery pełne koła (mniejsze z przodu, większe z tyłu) i „dyszel”, który trzyma starsza dziewczynka.

Nietypowe „zastosowanie” dla lalek znalazła Ewa Wendorffówna, później Felińska. W swoich wspomnieniach napisanych ma prośbę dzieci, które chciały, ,abym zostawiła wam na pamiątkę rys mego życia, zacząwszy od pierwszej młodości”"112, opisała swoją zabawę lalkami. „Byłam jeszcze wówczas wcale mała, panna Anna Rejentówna [- - ] udarowała mię gromadką lalek nadzwyczajnej piękności pod względem strojów. Było ich pewnie ze dwadzieścia, a wszystkie tak wytwornie ubrane, że w życiu nie widziałam zbioru tak pięknych materyj, jak te, które stroiły lalki moje. Wprawdzie oczy, które ledwie od lat kilku na świat patrzały, nie mogły widzieć wiele, i zwykle patrzą przez pryzmat, który każdą rzecz nową ubiera w tęczowe kolory. Patrząc zatem na zbiór lalek moich, pomyślałam, że chyba święci w niebie muszą się stroić w podobne sukienki. Ledwie mi to przemknęło przez głowę, zaraz przyszła myśl druga. Zachciało mi się z tych lalek utworzyć wizerunek nieba, aby sobie wyobrazić jak tam pięknie być musi"113. Tak też uczyniła, znalazła odpowiednie, mało uczęszczane przez domowników miejsce i tam zaniosła swoje „lalki przerobione w mej myśli na świętych". Odpowiednio je poukładała, wyznaczyła im role w zależności od bogactwa strojów i w tajemnicy przed wszystkimi przychodziła się tam modlić.

Zabawa w kościół czy odprawianie mszy nie była czymś wyjątkowym, gdyż dzieci obdarowywano zabawkami, które nazwać można religijnymi. Były to dla dziewcząt lalki w strojach zakonnych, dla chłopców, którzy w przyszłości mogli zostać duchownymi, stroje duchownych, miniaturo-

${ }^{111} \mathrm{~J}$. Schopenhauer, Gdańskie wspomnienia młodości, Gdańsk 2010 (oryg. niem. 1839), s. 100.

112 Pamiętniki z życia Ewy Felińskiej, Wilno 1856, s. 5.

113 Ibidem, s. 73. 
we naczynia liturgiczne (krucyfiksy, monstrancje, kielichy czy cyboria). Zabawki takie znano już w średniowieczu, ale najbardziej popularne były w wiekach XVI-XVIII ${ }^{114}$, wiele takich dziecięcych „zestawów” mszalnych zobaczyć można w europejskich muzeach (np. w Norymberdze). Wśród zabawek wymienionych w inwentarzu rzeczy należących do kupca świdnickiego Kaspra Helwika znalazły się także drewniane krucyfiksy, prawdopodobnie przeznaczone dla dzieci do zabawy ${ }^{115}$.

$*$

Na zakończenie rozważań na temat dawnych zabawek dziecięcych sięgnąć warto, podobnie jak na początku artykułu, do źródeł z początku wieku XIX. Z 1827 r. pochodzą dwa obrazy autorstwa Wilibalda Richtera wiążące się z rodziną Potockich, których nazwisko w kontekście zabawek pojawiało się już kilkakrotnie w niniejszym tekście. Pierwszy to akwarela, na której widzimy pokój dziecinny w pałacu w Łańcucie należącym od 1822 r. do Alfreda Potockiego. Podpis wskazuje, że dwaj wyobrażeni na niej chłopcy to Adam i Alfred Potoccy. Są to zapewne kuzyni, równolatkowie urodzeni w 1822 r., sportretowani w wieku około pięciu lat. Adam to syn Artura i Zofii z Branickich, a Alfred - syn brata Artura, Alfreda, właściciela Łańcuta. Chłopcy zostali przedstawieni na środku pokoju, w którym „mieszkali ze starym Andrzejem Bartkowskim", jak informuje podpis pod rysunkiem. Widzimy typowe chłopięce zabawki - koniki na patykach, biczyk, strzelbę, ale także figurki zwierzą - osiodłanego konika i egzotycznego wielbłąda na kółkach oraz figurki żołnierzy. Wśród zabawek leży również wojskowe nakrycie głowy ${ }^{116}$.

Drugie przedstawienie to rysunek ołówkiem, być może szkic do akwareli, ukazujący salę balową w krakowskiej kamienicy „Pod Baranami” będącej od 1822 r. własnością Artura Potockiego. Widać ustawiony w niej domek dziecinny i pięcioro bawiących się dzieci - dwóch chłopców i trzy dziewczynki. Chłopcy to znani nam już Alfred i Antoni, dziewczynki zaś to Aleksandra, Julia i Zofia. Pierwsza z nich to zapewne urodzona w 1818 r. córka Stanisława Septyma Potockiego i Katarzyny z Branickich. Wychowywała ją siostra matki, Zofia z Branickich Potocka, żona Artura. Julia i Zofia to siostry Alfreda, córki Alfreda i Julii z Lubomirskich. Panienki są nieco starsze niż chłopcy, Aleksandra i Julia mają bowiem po 9, a Zofia 7 lat. Narysowana sala to prawdziwy raj dla dzieci - oprócz domku znajduje się w niej wiele zabawek. Domek jest wielkości pozwalającej na swobodne wchodzenie do

114 J. Bujak, op. cit., s. 32-33.

${ }^{115}$ M. Gutkowska-Rychlewska, op. cit., s. 196.

${ }^{116}$ BJ, sygn. 2143, W. Richter, Pokój Alfreda i Adama Potockich w Łańcucie. 
niego i zabawę we wnętrzu.Jeden z chłopców, Alfred, stoi w drzwiach, drugi, Adam, siedzi na stojącym nieopodal koniu na biegunach. Dziewczynki mają do dyspozycji huśtawkę - są to umocowane na biegunach fotele. Ponadto widzimy leżące na podłodze obok domku przedmioty do zabaw chłopięcych - elementy uzbrojenia (szpadę i włócznię, a także żołnierskie nakrycie głowy) oraz dziewczęcych - lalkę, naczynia (dzbanki, wazę, kubki oraz drybus - naczynie służące do gotowania) ${ }^{117}$. Ta „wycieczka” w wiek XIX pokazuje, że nasze dzieci jednak miały do dyspozycji wiele różnorodnych zabawek i można przypuszczać, iż dotyczyło to również czasów przed rozbiorami.

Do XIX w. zabawka funkcjonowała w świadomości społecznej jako mało istotny przedmiot. Dopiero w drugiej połowie tego stulecia dostrzec można zainteresowanie zabawkami, najwcześniej we Francji i w Niemczech. Przejawia się to powstawaniem kolekcji zabawek, ale też, co ważniejsze, pojawieniem się zabawki w kręgu zainteresowań pedagogów. Przed wiekiem XIX spotykamy niewiele wypowiedzi na temat roli zabawki w życiu dziecka czy procesie jego socjalizacji. Wprawdzie już w starożytności zwrócono uwagę na zabawkę i jej funkcje, co uczynił Platon, a za nim inni antyczni myśliciele, ale kolejne epoki jakby o niej zapomniały. Wiązało się to, rzecz jasna, z sytuacją dziecka i jego statusem w rodzinie i społeczeństwie.Przed końcem XVIII w. pewne uwagi na temat zabawek odnotowali w swych pismach Jan Ludwik Vives, J. A. Komeński czy John Locke, niestety polscy pisarze nie wypowiadali się na ten temat ${ }^{118}$.

Stosunek do dziecięcych zabawek ulegał zmianom - od nieobecności i niedostrzegania, stopniowo przechodzono do dostrzegania i podkreślania ich roli w rozwoju i edukacji dziecka. Był to proces długotrwały, podobnie jak ten zmierzający do zrozumienia istoty dzieciństwa. Interesujące wydają się analogie między niedostrzeganiem zabawek w polskich rozważaniach nad wychowaniem przed połową wieku XIX i skąpymi informacjami źródłowymi na ten temat.

Powyższe rozważania stanowią pierwszą próbę zebrania i wstępnego opracowania informacji na temat zabawek dziecięcych na ziemiach polskich w okresie pierwszej Rzeczypospolitej. Dla uzupełnienia i poszerzenia otrzymanego obrazu konieczne wydają się dalsze poszukiwania, przede wszystkim w zasobach muzeów i kolekcjach prywatnych. Interesujące byłyby zapewne również studia nad sposobami wytwarzania zabawek, handlem nimi - zarówno miejscowym, sprzedażą na straganach, podczas

117 BJ, sygn. 2151, W. Richter, Domek dziecinny w sali balowej w Krakowie pod Baranami rok 1827.

${ }^{118}$ K. Kabacińska, Zabawka $w$ dawnych pogladach pedagogicznych, w: Dawne i wspótczesne zabawki dziecięce, s. 123-135. 
jarmarków, jak i importem z zagranicznych ośrodków wytwarzających zabawki (m.in. z ziem niemieckich). Niestety skromne wzmianki o przedmiotach dziecięcych zabaw w źródłach pisanych nie pozwalają na prześledzenie ich losów w polskich warunkach, nieznane są na przykład przypadki przechowywania zabawek w zbiorach rodzinnych, czy wręcz użytkowania ich przez kilka pokoleń. Do nielicznych należą informacje o sposobach uzyskiwania zabawek - najczęściej możemy domniemywać, że były to prezenty od najbliższych, ewentualnie od znajomych lub przyjaciół rodziny. Część zabawek została zapewne przywieziona z zagranicy - przez podróżujących Polaków lub też przez obcych kupców i stąd ważnym, obiecującym kierunkiem dalszych poszukiwań okazać się mogą studia porównawcze, skonfrontowanie stanu posiadania polskich muzeów i zapisów w źródłach pisanych z materiałem z innych krajów europejskich, co w pewnym zakresie uczyniono w niniejszym artykule, ale co wydaje się potrzebne w szerszym kontekście.

\section{“The Toys Were Plentiful”. Children's Toys in Polish Lands during the Middle Ages and the Modern Era}

Children have been playing since time immemorial, with pebbles, sticks and fruit as their first playthings. In time games involved specially prepared objects. Different cultures and periods feature similar toys due to certain regularities of a child's development and similarities governing the progress of societies. Children's toys from the past can be divided into several groups taking into consideration such criteria as the child's age and gender and the function of the given toy. The first group thus includes toys associated with infancy and early childhood, such as rattles. The slightly older child played with spinning wheels and pin wheels. At the consecutive stage toys differed depending on the child's gender and future duties, with the youngsters imitating the observed occupations and behaviour of the adults. Girls "assuming" the roles of grown women had "girlish" toys preparing them for maternity they played with dolls, which fulfilled the function of children, and the games of future housewives involved miniature cooking utensils and furniture as well as doll houses. Since masculine occupations were much more numerous and varied boys had their disposal miniature tools preparing them for assorted professional roles and crafts (boats, wagons). The most popular boys' toys were connected with the military occupations of grown men - weapons, toy soldiers, and hobby horses. Children also played with religious objects while imitating priests officiating at funerals, celebrating Holy Mass, etc. With the passage of time, the development of civilisation, growing specialisations and the rise of new professions the range of toys increased and became diversified.

Translated by Aleksandra Rodzińska-Chojnowska 